\title{
Ferrimonas futtsuensis sp. nov. and Ferrimonas kyonanensis sp. nov., selenate-reducing bacteria belonging to the Gammaproteobacteria isolated from Tokyo Bay
}

\author{
Tatsunori Nakagawa,† Takao lino, Ken-ichiro Suzuki \\ and Shigeaki Harayama
}

Correspondence Tatsunori Nakagawa nakatats@brs.nihon-u.ac.jp
NITE Biological Resource Center, National Institute of Technology and Evaluation (NITE), Kazusakamatari 2-5-8, Kisarazu, Chiba 292-0818, Japan
Selenium (Se) is a required element for the synthesis of the essential amino acid selenocysteine, but it is highly toxic at micromolar concentrations. Selenate $\left[\mathrm{SeO}_{4}^{2-}, \mathrm{Se}(\mathrm{VI})\right]$ and selenite $\left[\mathrm{SeO}_{3}^{2-}, \mathrm{Se}(\mathrm{IV})\right]$ are distributed in oxic environments, while insoluble elemental selenium $\left(\mathrm{Se}^{0}\right)$ is distributed in anaerobic environments (Conde \& Sanz Alaejos, 1997). The reduction of selenium oxyanions occurs primarily via microbial dissimilatory reduction (Stolz \& Oremland, 1999). Moreover, the microbial reduction of

†Present address: Department of Agricultural and Biological Chemistry, Nihon University, 1866 Kameino, Fujisawa, Kanagawa 252-8510, Japan.

Abbreviation: DAPI, 4',6-diamidino-2-phenylindole.

The GenBank/EMBL/DDBJ accession numbers for the 16S rRNA gene sequences of Ferrimonas futtsuensis FUT366 $1^{\top}$ and Ferrimonas kyonanensis Asr22-7 $7^{\top}$ are AB245515 and AB245514, respectively.

Transmission electron micrographs of cells of strains FUT366 $1^{\top}$ and Asr22- $7^{\top}$, figures showing the effects of temperature, $\mathrm{NaCl}$ concentration and selenate concentration on growth of these two strains and a table detailing their fatty acid contents are available as supplementary material in IJSEM Online. soluble Se(VI) to insoluble $\mathrm{Se}^{0}$ is an important process in the removal of $\mathrm{Se}(\mathrm{VI})$ from Se-contaminated water. In recent years, several bacteria capable of reducing selenate to elemental selenium have been isolated from different environments. These isolates include Bacillus sp. SF-1 from a selenium-polluted sediment (Fujita et al., 1997), Bacillus selenitireducens MLS10 ${ }^{\mathrm{T}}$ from alkaline lake sediments (Switzer Blum et al., 1998), Sulfurospirillum barnesii SES-3 ${ }^{\mathrm{T}}$ from freshwater sediments (Stolz et al., 1999), Selenihalanaerobacter shriftii DSSe- $1^{\mathrm{T}}$ from deep-sea sediments (Switzer Blum et al., 2001), Salana multivorans Se$3111^{\mathrm{T}}$ from an aerobic bioreactor (von Wintzingerode et al., 2001) and Citrobacter freundii Iso-Z7 from seleniumcontaminated sediment (Zhang et al., 2004). Recently, a dissimilatory metal-ion-reducing bacterium, Shewanella oneidensis $\mathrm{MR}-\mathrm{1}^{\mathrm{T}}$, within the Gammaproteobacteria was found to reduce selenite to elemental selenium (Klonowska et al., 2005). Here we report the characterization of novel mesophilic, facultatively anaerobic bacteria belonging to the Gammaproteobacteria, which are related to the genus Ferrimonas and are able to reduce selenate to elemental selenium. Given that the type strain of the type species of the 
genus Ferrimonas, Ferrimonas balearica $\mathrm{PAT}^{\mathrm{T}}$, is known to be an iron(III)- and manganese(IV)-reducing bacterium (Rosselló-Mora et al., 1995), the reduction of selenate, selenite, iron(III) and manganese(IV) was investigated in the novel isolates and in the type strains of recognized members of the genus Ferrimonas.

Sediment samples were collected with an Eckman grabber from a mudflat at Futtsu beach on the coast of Tokyo Bay, Japan. Black-coloured sediments were recovered from cores by means of plastic syringes, immediately put into $150 \mathrm{ml}$ sterilized serum bottles containing $100 \mathrm{ml}$ modified bicarbonate-buffered (MBB) medium without electron donor and acceptor and then sealed with a butyl rubber cap under a gas phase of $100 \% \mathrm{~N}_{2}$. The samples were transferred to our laboratory within a few hours. A sample of the slurry $(1 \mathrm{ml})$ was used to inoculate $30 \mathrm{ml} \mathrm{MBB}$ medium that was prepared anaerobically under $\mathrm{N}_{2} / \mathrm{CO}_{2}(80: 20$, v/v; Widdel \& Bak, 1992), the gas mixture being supplied through a deoxygenized gas pressure injector (IP-8; Sanshin Industrial). The basal medium was composed of $20 \mathrm{~g} \mathrm{NaCl}$ $\mathrm{l}^{-1}, 3 \mathrm{~g} \mathrm{MgCl}_{2} \cdot 6 \mathrm{H}_{2} \mathrm{O} \mathrm{l}^{-1}, 0 \cdot 15 \mathrm{~g} \mathrm{CaCl}_{2} \cdot 2 \mathrm{H}_{2} \mathrm{O} \mathrm{l}^{-1}, 0 \cdot 25 \mathrm{~g}$ $\mathrm{NH}_{4} \mathrm{Cl} \mathrm{l}^{-1}, 0 \cdot 2 \mathrm{~g} \mathrm{KH}_{2} \mathrm{PO}_{4} \mathrm{l}^{-1}$ and $0.5 \mathrm{~g} \mathrm{KCl} \mathrm{l}^{-1}$. The following were added per litre of the basal medium: $1 \mathrm{ml}$ non-chelated trace element mixture (Widdel et al., 1983), $1 \mathrm{ml}$ selenite/tungstate solution $\left(0 \cdot 4 \mathrm{~g} \mathrm{NaOH} \mathrm{l}{ }^{-1}, 6 \mathrm{mg}\right.$ $\left.\mathrm{Na}_{2} \mathrm{SeO}_{3} \cdot 5 \mathrm{H}_{2} \mathrm{O} \quad l^{-1}, 8 \mathrm{mg} \mathrm{Na} \mathrm{NO}_{4} \cdot 2 \mathrm{H}_{2} \mathrm{O} \mathrm{l}^{-1}\right), 30 \mathrm{ml}$ bicarbonate solution $\left(84 \mathrm{~g} \mathrm{NaHCO}_{3} \mathrm{l}^{-1}\right), 1 \mathrm{ml}$ vitamin mixture [40 mg 4-aminobenzoic acid $\mathrm{l}^{-1}, 10 \mathrm{mg}$ D-biotin, $100 \mathrm{mg}$ nicotinic acid $\mathrm{l}^{-1}, 50 \mathrm{mg}$ calcium D-pantothenate $\mathrm{l}^{-1}$ and $150 \mathrm{mg}$ pyridoxine dihydrochloride $\mathrm{l}^{-1}$ dissolved in $10 \mathrm{mM}$ sodium phosphate buffer $(\mathrm{pH} 7 \cdot 1)], 1 \mathrm{ml}$ thiamine solution $\left[100 \mathrm{mg}\right.$ thiamine chloride dihydrochloride $\mathrm{l}^{-1}$ dissolved in $25 \mathrm{mM}$ sodium phosphate buffer ( $\mathrm{pH} \mathrm{3 \cdot 4)]} \mathrm{and}$ $1 \mathrm{ml}$ vitamin $\mathrm{B}_{12}$ solution (50 mg cyanocobalamine $\mathrm{l}^{-1}$ dissolved in distilled water). The $\mathrm{pH}$ of the medium was adjusted with $1 \mathrm{M} \mathrm{HCl}$ or $1 \mathrm{M} \mathrm{CaCO}_{3}$ to $7 \cdot 0$. Selenate $(1 \mathrm{M})$ and lactate $(2 \mathrm{M})$ were separately autoclaved and added to the medium to a final concentration of $5 \mathrm{mM}$ as an electron acceptor and electron donor, respectively. Serum bottles (70 $\mathrm{ml}$ ) sealed with butyl rubber stoppers under a headspace of $\mathrm{N}_{2} / \mathrm{CO}_{2}(80: 20, \mathrm{v} / \mathrm{v})$ were used for cultivation. The inoculated cultures were incubated at $25^{\circ} \mathrm{C}$ in the dark and shaken by hand for a few seconds every week. An orange- to red-coloured precipitate formed in the culture as a result of the formation of insoluble elemental selenium. Several elemental selenium-forming enrichment cultures were established by subculturing twice in the same medium. The enrichment cultures were diluted in anaerobic molten agar $(1 \cdot 1 \%, \mathrm{w} / \mathrm{v}$; Bacto $)$ of the same medium, and orangeto red-coloured colonies were obtained in the agar shake tubes. Purification of the colonies by the agar shake tube method was repeated twice before aerobic plating on a marine agar 2216 (MA; Difco) plate. A single colony on the MA plate was incubated back into MBB medium containing $5 \mathrm{mM}$ selenate and $5 \mathrm{mM}$ lactate and, after several days, redcoloured precipitate developed in the culture due to the formation of insoluble elemental selenium. This isolate was designated strain FUT3661 ${ }^{\mathrm{T}}$. The purity of the final culture was confirmed by microscopic examination and partial sequencing of the $16 \mathrm{~S}$ rRNA gene using appropriate PCR primers.

Littleneck clams, Ruditapes philippinarum, were collected at Kyonan beach on the coast of Tokyo Bay and maintained in an atmosphere of $100 \% \mathrm{CO}_{2}$ during transfer to our laboratory. The clams were dissected, and approximately $1 \mathrm{~g}$ alimentary tract homogenate was used for the isolation of bacteria. Serial decimal dilutions $\left(10^{-1}-10^{-10}\right)$ of the alimentary tract extracts were made with saline; $0 \cdot 1 \mathrm{ml}$ dilutions were spread on LYPm agar plates and cultivated at room temperature (approximately $23^{\circ} \mathrm{C}$ ) in an atmosphere that contained $100 \% \mathrm{CO}_{2}$ for 1 month or more. LYPm medium was composed of $10 \mathrm{~g} \alpha$-lactose, $10 \mathrm{~g}$ yeast extract (Difco), $5 \mathrm{~g}$ polypeptone (Nihon Seiyaku), $20 \mathrm{~g} \mathrm{NaCl}$, $0.025 \mathrm{~g}$ Tween $80,5 \mathrm{ml}$ of salt solution and $1 \mathrm{ml}$ distilled water; the initial $\mathrm{pH}$ of the medium was adjusted to $6 \cdot 0$. The salt solution contained (per litre of distilled water) $40 \mathrm{mg}$ $\mathrm{MgSO}_{4} .7 \mathrm{H}_{2} \mathrm{O}, 2 \mathrm{mg} \mathrm{MnSO}{ }_{4} \cdot 4 \mathrm{H}_{2} \mathrm{O}, 2$ mg FeSO $4.7 \mathrm{H}_{2} \mathrm{O}$ and $2 \mathrm{mg} \mathrm{NaCl}$. Visible colonies grown on LYPm agar medium were collected and the purification procedure was repeated several times until the cultures were deemed to be pure. The first pure culture was designated strain Asr $22-7^{\mathrm{T}}$. The purity of the final culture was confirmed by microscopic examination and partial sequencing of the 16S rRNA gene using appropriate PCR primers. Strain Asr22-7 ${ }^{\mathrm{T}}$ was maintained on MA plates. Several experiments for selenate reduction by strain Asr $22-7^{\mathrm{T}}$ were performed anaerobically with $\mathrm{MBB}$ medium. An orange-coloured precipitate developed in the culture bottle during incubation at $25^{\circ} \mathrm{C}$ as a result of the formation of insoluble elemental selenium.

Cells were observed under a phase-contrast microscope (AX70; Olympus). Gram staining was carried out using a standard procedure (Hucker \& Conn, 1923) with Enterococcus faecalis NBRC $100481^{\mathrm{T}}$ as a positive control for the staining. Cells of strain FUT366 $1^{\mathrm{T}}$ grown to lateexponential phase at $30^{\circ} \mathrm{C}$ in marine broth $2216(\mathrm{MB}$, $\mathrm{pH} 7 \cdot 0$; Difco) supplemented with $\mathrm{NaCl}$ to $3 \cdot 0 \%(\mathrm{w} / \mathrm{v})$, and those of strain Asr22- $7^{\mathrm{T}}$ grown to the same growth phase in $\mathrm{MB}$ at $25^{\circ} \mathrm{C}$, were negatively stained with $1 \%(\mathrm{w} / \mathrm{v})$ phosphotungstic acid and observed under a Hitachi transmission electron microscope at an accelerating voltage of $80 \mathrm{kV}$. Cells of strain FUT3661 ${ }^{\mathrm{T}}$ were Gram-negative, motile rods $(0.7-0.9 \times 0.4-0.7 \mu \mathrm{m})$, as were those of strain Asr22-7 $7^{\mathrm{T}}(0 \cdot 7-1 \cdot 1 \times 0 \cdot 5-0 \cdot 8 \mu \mathrm{m})$. Cells of both strains possessed a polar monotrichous flagellum (see Supplementary Fig. S1 in IJSEM Online). In most cases, strains FUT3661 ${ }^{\mathrm{T}}$ and Asr $22-7^{\mathrm{T}}$ appeared as single cells. No endospore production was observed.

Strains FUT3661 ${ }^{\mathrm{T}}$ and Asr $22-7^{\mathrm{T}}$ grew rapidly both in MB and on MA under aerobic conditions. The doubling time of strain FUT3661 ${ }^{\mathrm{T}}$ incubated aerobically in $\mathrm{MB}(\mathrm{pH} 7 \cdot 0$; $\mathrm{NaCl} 3.0 \%$ ) at $30^{\circ} \mathrm{C}$ was $48 \mathrm{~min}$, whereas that of strain Asr $22-7^{\mathrm{T}}$ incubated aerobically in $\mathrm{MB}(\mathrm{pH} 7 \cdot 0 ; \mathrm{NaCl} 2 \cdot 0 \%)$ at $25^{\circ} \mathrm{C}$ was $78 \mathrm{~min}$. To determine the optimum growth 
temperature and $\mathrm{NaCl}$ concentration under selenatereducing conditions, tubes with $\mathrm{MBB}$ medium containing $5 \mathrm{mM}$ selenate and $5 \mathrm{mM}$ lactate were inoculated with the two novel strains and cultivated anaerobically without shaking in the dark for 2 weeks (Table 1). Growth of the strains was determined according to the optical density of the tubes at $600 \mathrm{~nm}$. All experiments were conducted in duplicate. Strain FUT3661 $1^{\mathrm{T}}$ grew at temperatures between $15 \cdot 0$ and $30.0{ }^{\circ} \mathrm{C}$, with optimal growth at $30.0{ }^{\circ} \mathrm{C}$ (see Supplementary Fig. S2 in IJSEM Online). Strains FUT3661 ${ }^{\mathrm{T}}$ and Asr $22-7^{\mathrm{T}}$ required $\mathrm{NaCl}$ for growth (see Supplementary Fig. S3 in IJSEM Online). The ability to grow at $\mathrm{pH} 5 \cdot 5-9 \cdot 0$ was tested in $\mathrm{MBB}$ medium containing $5 \mathrm{mM}$ selenate and $5 \mathrm{mM}$ lactate.

To clarify the potential utilization of electron donors and carbon sources under selenate-reducing conditions, the two strains were cultivated anaerobically in pressure-proof culture tubes (Sanshin Industrial) containing MBB medium supplemented with $5 \mathrm{mM}$ selenate and one of the following potential carbon sources: $0 \cdot 1 \%(\mathrm{w} / \mathrm{v})$ yeast extract, $0 \cdot 1 \%(\mathrm{w} / \mathrm{v})$ tryptone, $0 \cdot 1 \%(\mathrm{w} / \mathrm{v})$ Casamino acids, $5 \mathrm{mM}$ D-glucose, $5 \mathrm{mM}$ D-fructose, $5 \mathrm{mM}$ D-maltose, $5 \mathrm{mM}$ D-xylose, $5 \mathrm{mM}$ D-galactose, $5 \mathrm{mM}$ citrate, $5 \mathrm{mM}$ fumarate, $5 \mathrm{mM}$ malate, $5 \mathrm{mM}$ pyruvate, $5 \mathrm{mM}$ succinate,
$5 \mathrm{mM}$ propionate, $5 \mathrm{mM}$ lactate, $5 \mathrm{mM}$ acetate, $5 \mathrm{mM}$ ethanol, $5 \mathrm{mM}$ methanol, $0 \cdot 1 \%(\mathrm{w} / \mathrm{v})$ L-glutamate, $0 \cdot 1 \%$ $(\mathrm{w} / \mathrm{v})$ glycine, $0.1 \%(\mathrm{w} / \mathrm{v})$ L-serine, $0.1 \%(\mathrm{w} / \mathrm{v}) \quad$ Lphenylalanine and $0 \cdot 1 \%(\mathrm{w} / \mathrm{v})$ L-proline. Each tube was cultivated anaerobically without shaking in the dark for 2 weeks. All experiments were conducted in duplicate. The concentration of selenate in the liquid medium was analysed by HPLC (2695; Waters). Strains FUT3661 ${ }^{\mathrm{T}}$ and Asr22-7 ${ }^{\mathrm{T}}$ could not utilize acetate or glutamate, in contrast to the type strains of F. balearica and Ferrimonas marina (Table 1). All potential electron acceptors, e.g. $5 \mathrm{mM}$ selenate $\left(\mathrm{Na}_{2} \mathrm{SeO}_{4}\right)$, $5 \mathrm{mM}$ selenite $\left(\mathrm{Na}_{2} \mathrm{SeO}_{3}\right), 0.01 \mathrm{~g}$ iron(III) oxyhydroxide $\left[\mathrm{Fe}(\mathrm{OH})_{3}\right] \mathrm{ml}^{-1}$ (Lovley \& Phillips, 1986), $5 \mathrm{mM}$ iron(III) citrate $\left(\mathrm{FeC}_{6} \mathrm{H}_{5} \mathrm{O}_{7}\right), 5 \mathrm{mM}$ arsenate $\left(\mathrm{Na}_{2} \mathrm{HAsO}_{4}\right), 0.03 \mathrm{~g}$ manganese(IV) oxide $\left(\mathrm{MnO}_{2}\right) \mathrm{ml}^{-1}, 0 \cdot 01 \mathrm{~g}$ elemental sulfur $\left(\mathrm{S}^{0}\right) \mathrm{ml}^{-1}, 5 \mathrm{mM}$ thiosulfate $\left(\mathrm{Na}_{2} \mathrm{~S}_{2} \mathrm{O}_{3}\right), 5 \mathrm{mM}$ sulfate $\left(\mathrm{Na}_{2} \mathrm{SO}_{4}\right), 5 \mathrm{mM}$ nitrate $\left(\mathrm{NaNO}_{3}\right)$ and $20 \%$ (in the head space) oxygen $\left(\mathrm{O}_{2}\right)$, were tested in $\mathrm{MBB}$ medium supplemented with $5 \mathrm{mM}$ lactate. All experiments were conducted in duplicate. The concentrations of selenate, arsenate and nitrate in the cultivated tube were analysed via HPLC (2695; Waters). The amounts of total arsenic [As(V) and $\mathrm{As}(\mathrm{III})]$, reduced manganese and nitrite in the cultures were analysed with Pack Test kits (WAK-As, $-\mathrm{Mn}$ and $-\mathrm{NO}_{2}$; Kyoritsu Chemical-Check Lab). The amount of iron(II) in

Table 1. Phenotypic characteristics that differentiate strains FUT3661 ${ }^{\top}$ and Asr $22-7^{\top}$ from other strains within the genus Ferrimonas

Strains: 1, FUT3661 ${ }^{\mathrm{T}}$; 2, Asr22-7 ${ }^{\mathrm{T}}$; 3, F. balearica PAT ${ }^{\mathrm{T}}$ (Rosselló-Mora et al., 1995; Katsuta et al., 2005); 4, F. marina A4D-4 ${ }^{\mathrm{T}}$ (Katsuta et al., 2005); 5, F. balearica A2A-18 (Katsuta et al., 2005); 6, Ferrimonas sp. A3B-58 (Katsuta et al., 2005); 7, Ferrimonas sp. A3B-57-2 (Katsuta et al., 2005). +, Positive reaction; -, negative reaction; ND, no data. Production of $\mathrm{H}_{2} \mathrm{~S}$ was investigated by using TSI plates. $\mathrm{Fe}(\mathrm{OH})_{3}, \mathrm{HAsO}_{4}^{2-}, \mathrm{MnO}_{2}$ and $\mathrm{S}^{0}$ were utilized by strains $1-4$. Fe(III) citrate, $\mathrm{O}_{2}$ and lactate were utilized by all strains. $\mathrm{NO}_{3}^{-}$was utilized by strains $1-3 . \mathrm{SO}_{4}^{2-}$ was not utilized by strains $1-4$.

\begin{tabular}{|c|c|c|c|c|c|c|c|}
\hline Characteristic & 1 & 2 & 3 & 4 & 5 & 6 & 7 \\
\hline Growth at $42^{\circ} \mathrm{C}$ & - & - & + & - & + & $\mathrm{ND}$ & $\mathrm{ND}$ \\
\hline $\mathrm{NaCl}$ concentration for growth (\%) & $0 \cdot 7-5 \cdot 0$ & $2 \cdot 0-5 \cdot 0$ & $0 \cdot 5-7 \cdot 5$ & $1 \cdot 5-5 \cdot 5$ & $0 \cdot 5-7 \cdot 5$ & $\mathrm{ND}$ & ND \\
\hline Production of $\mathrm{H}_{2} \mathrm{~S}$ & + & + & + & - & + & $\mathrm{ND}$ & ND \\
\hline Gelatinase & + & + & - & ND & ND & $\mathrm{ND}$ & ND \\
\hline \multicolumn{8}{|l|}{ Electron acceptor: } \\
\hline $\mathrm{SeO}_{4}^{2-}$ & + & + & $+^{*}$ & $-*$ & $+^{*}$ & $+^{*}$ & $+^{*}$ \\
\hline $\mathrm{SeO}_{3}^{2-}$ & - & - & $+^{*}$ & $-{ }^{\star}$ & $+^{*}$ & $+^{\star}$ & $+^{\star}$ \\
\hline $\mathrm{S}_{2} \mathrm{O}_{3}^{-}$ & + & - & $+^{*}$ & $-{ }^{*}$ & $\mathrm{ND}$ & $\mathrm{ND}$ & $\mathrm{ND}$ \\
\hline \multicolumn{8}{|l|}{ Utilization of: } \\
\hline D-Glucose & - & - & - & + & $\mathrm{ND}$ & ND & ND \\
\hline DNA G $+C$ content $(\mathrm{mol} \%)$ & 58 & 57 & 60 & 61 & 60 & $\mathrm{ND}$ & ND \\
\hline \multirow[t]{2}{*}{ Major fatty acids } & $\mathrm{C}_{16: 0}$ & $\mathrm{C}_{16: 0}$ & $\mathrm{C}_{16: 0}$ & $\mathrm{C}_{16: 0}$ & $\mathrm{C}_{18: 1} \omega 9 c$ & $\mathrm{C}_{16: 0}$ & $\mathrm{C}_{16: 0}$ \\
\hline & $\mathrm{C}_{18: 1} \omega 9 c$ & $\mathrm{C}_{18: 1} \omega 9 c$ & $\mathrm{C}_{18: 1} \omega 9 c$ & $\mathrm{C}_{18: 1} \omega 9 c$ & & $\mathrm{C}_{18: 1} \omega 9 c$ & $\mathrm{C}_{18: 1} \omega 9 c$ \\
\hline
\end{tabular}

${ }^{*}$ Also investigated in the present study. 
the cultures was measured with the phenanthroline method (Tamura et al., 1974). Hydrogen sulfides produced from elemental sulfur, thiosulfate and sulfate in the incubated media were measured with the methylene blue formation reaction method (Cline, 1969). The production of nitrite from nitrate was also tested via the API $20 \mathrm{NE}$ system (bioMérieux). Cell density in the cultures was determined by counting cells using epifluorescence microscopy after filtration of paraformaldehyde-fixed cells stained with 4',6-diamidino-2-phenylindole (DAPI) through polycarbonate Nucleopore (Millipore) membranes $(0 \cdot 2 \mu \mathrm{m}$ pore size) (Porter \& Feig, 1980). Strain FUT3661 ${ }^{\mathrm{T}}$ was able to utilize selenate, iron(III) oxyhydroxide, iron(III) citrate, arsenate, manganese(IV) oxide, elemental sulfur, thiosulfate, nitrate and oxygen (Table 1), the yield with each electron acceptor being $6 \times 10^{7}, 1 \times 10^{8}, 6 \times 10^{7}, 6 \times 10^{7}, 6 \times 10^{7}, 1 \times 10^{8}$, $2 \times 10^{8}, 6 \times 10^{7}$ and $6 \times 10^{7}$ cells ml $^{-1}$, respectively. Nitrate was reduced to nitrite. No growth of strain FUT3661 ${ }^{\mathrm{T}}$ was observed in the culture with selenite $\left(1 \times 10^{6}\right.$ cells ml $\left.^{-1}\right)$. Strain Asr $22-7^{\mathrm{T}}$ was able to utilize selenate, iron(III) oxyhydroxide, iron(III) citrate, arsenate, manganese(IV) oxide, elemental sulfur, nitrate and oxygen (Table 1), the yield with each electron acceptor being $6 \times 10^{7}$, $6 \times 10^{7}, 1 \times 10^{8}, 9 \times 10^{7}, 5 \times 10^{7}, 1 \times 10^{8}, 8 \times 10^{7}$ and $2 \times 10^{8}$ cells ml $^{-1}$, respectively. Nitrate was reduced to nitrite. No growth of strain Asr $22-7^{\mathrm{T}}$ was observed in the culture with selenite.

The optimal selenate concentration for growth in test tubes containing MBB medium supplemented with several concentrations of selenate and $5 \mathrm{mM}$ lactate was determined at $30{ }^{\circ} \mathrm{C}$ for strain FUT3661 ${ }^{\mathrm{T}}$ and at $25^{\circ} \mathrm{C}$ for strain Asr22- $7^{\mathrm{T}}$ without shaking in the dark for 2 weeks. Growth was assessed based on the optical density of the tubes at $600 \mathrm{~nm}$. All experiments were conducted in duplicate. The optimal selenate concentrations for growth of strains FUT3661 ${ }^{\mathrm{T}}$ and Asr $22-7^{\mathrm{T}}$ were 12.5 and $5.0 \mathrm{mM}$, respectively (see Supplementary Fig. S4 in IJSEM Online). The time courses of the reduction of selenate and concomitant bacterial growth of strains FUT3661 ${ }^{\mathrm{T}}$ and Asr22-7 ${ }^{\mathrm{T}}$ were examined in $150 \mathrm{ml}$ serum bottles containing $120 \mathrm{ml}$ of anaerobic MBB medium supplemented with $12.5 \mathrm{mM}$ selenate, $10 \mathrm{mM}$ lactate and $0.01 \%(\mathrm{w} / \mathrm{v})$ yeast extract for strain FUT3661 ${ }^{\mathrm{T}}$, and $5 \mathrm{mM}$ selenate, $5 \mathrm{mM}$ lactate and $0.01 \%(\mathrm{w} / \mathrm{v})$ yeast extract for strain Asr22-7 ${ }^{\mathrm{T}}$ (Fig. 1). Cultures were sampled periodically and analysed for cell density by staining paraformaldehyde-fixed cells with DAPI. The experiments were conducted in triplicate. The concentrations of selenate decreased, accompanied by precipitation of elemental selenium, during growth of the two strains. Thus, strains FUT3661 ${ }^{\mathrm{T}}$ and Asr $22-7^{\mathrm{T}}$ were found to be facultatively anaerobic, selenate-reducing chemo-organotrophs.

The abilities of cultured strains of the genus Ferrimonas to reduce selenate and selenite were also examined. F. balearica $\mathrm{PAT}^{\mathrm{T}}\left(=\mathrm{DSM} 9799^{\mathrm{T}}\right), \quad$ F. balearica A2A-18 $(=\mathrm{MBIC}$ 06164), Ferrimonas sp. A3B-58 (=MBIC 06350) and

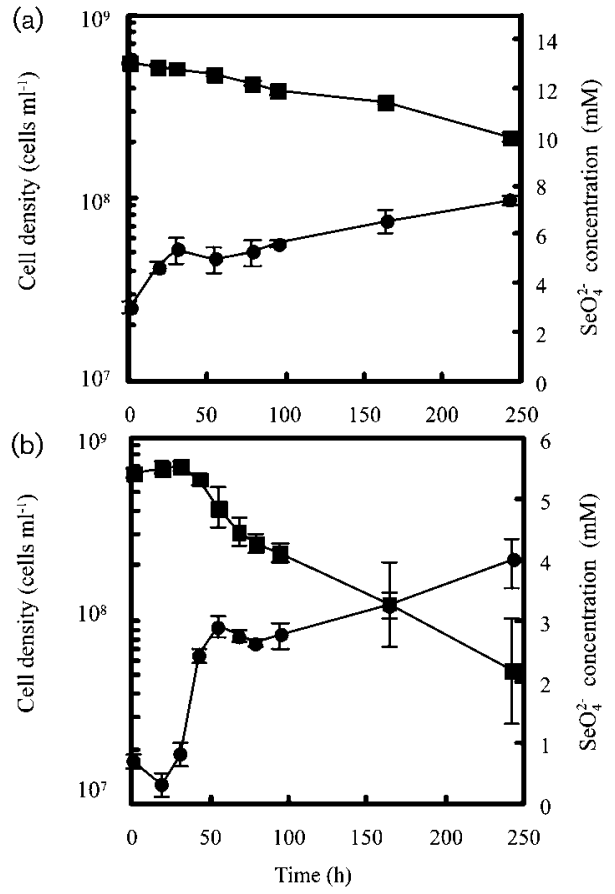

Fig. 1. Time course of selenate reduction (filled squares) and concomitant bacterial growth (filled circles) of strains FUT3661 ${ }^{\top}$ (a) and Asr22-7 ${ }^{\top}$ (b).

Ferrimonas sp. A3B-57-2 (=MBIC 06481) were able to utilize both selenate and selenite, whereas no growth of $F$. marina $\mathrm{A} 4 \mathrm{D}-4^{\mathrm{T}}\left(=\mathrm{MBIC} 06480^{\mathrm{T}}\right)$ incubated with selenate or selenite was observed.

Strains FUT3661 ${ }^{\mathrm{T}}$ and Asr $22-7^{\mathrm{T}}$ produced $\mathrm{H}_{2} \mathrm{~S}$ on triplesugar iron (TSI) plates (Difco), and hydrolysed gelatin (API $20 \mathrm{NE}$ system; bioMérieux). Strain Asr $22-7^{\mathrm{T}}$ showed a positive reaction for arginine dehydrolase on the same API system.

For quinone analyses, strain FUT366 $1^{\mathrm{T}}$ was grown in MB containing $3 \%(\mathrm{w} / \mathrm{v}) \mathrm{NaCl}$ at $\mathrm{pH} 7 \cdot 0$ at $30^{\circ} \mathrm{C}$, while strain Asr22-7 $7^{\mathrm{T}}$ was grown in $\mathrm{MB}$ at $\mathrm{pH} 7 \cdot 0$ at $25^{\circ} \mathrm{C}$. Isoprenoid quinones were extracted from freeze-dried cells with chloroform/methanol $(2: 1, \mathrm{v} / \mathrm{v})$ and fractionated by TLC (Collins et al., 1977). Menaquinone and ubiquinone for the LC-MS (LCMS-8000 $\alpha$, Shimadzu) analysis were excised from the chromatographs. The LC-MS analysis indicated that strains FUT3661 ${ }^{\mathrm{T}}$ and Asr22-7 ${ }^{\mathrm{T}}$ contained menaquinones (MK-7) and ubiquinones (Q-7 and Q-8) as the predominant isoprenoid quinones. Similarly, strains of the genus Ferrimonas also contained MK-7, Q-7 and Q-8 (Katsuta et al., 2005). The major cellular fatty acid contents of strains FUT3661 ${ }^{\mathrm{T}}$ and Asr22-7 ${ }^{\mathrm{T}}$ were analysed by GC (Agilent GC 6890N; MIDI Inc.). The two novel strains were grown to late-exponential growth phase in $\mathrm{MB}$ containing $3 \% \mathrm{NaCl}$ at $\mathrm{pH} 7 \cdot 0$ at $30^{\circ} \mathrm{C}$, and in $\mathrm{MB}$ at $\mathrm{pH} 7 \cdot 0$ at $25^{\circ} \mathrm{C}$ and the cellular fatty acids were extracted from the cells and converted to methyl esters according to the manufacturer's 
recommendations. The major cellular fatty acids of strains FUT3661 ${ }^{\mathrm{T}}$ and Asr22-7 $7^{\mathrm{T}}$ were $\mathrm{C}_{16: 1} \omega 9 \mathrm{c}$ and $\mathrm{C}_{16: 0}$ (see Supplementary Table S1 in IJSEM Online), contrasting with the results for members of the genus Ferrimonas grown in MB (Katsuta et al., 2005) (Table 1).

Genomic DNA was extracted from cells grown in MB. The $\mathrm{G}+\mathrm{C}$ content of the DNA of strains FUT3661 ${ }^{\mathrm{T}}$ and Asr22$7^{\mathrm{T}}$ was $58 \cdot 1$ and $57 \cdot 2 \mathrm{~mol} \%$, respectively, as determined by direct analysis of the deoxyribonucleosides using HPLC (Tamaoka \& Komagata, 1984; Mesbah et al., 1989). The $16 \mathrm{~S}$ rRNA gene was amplified by PCR using Eubac27F and 1492R primers (DeLong, 1992). The sequence of the PCR product was directly determined in both strands by the dideoxynucleotide chain-termination method with a BigDye v3.1 sequencing kit (PE Applied Biosystems) and a DNA sequencer (model 3100; PE Applied Biosystems) according to the manufacturers' recommendations. We searched for sequences similar to the $16 \mathrm{~S}$ rRNA gene sequences of these strains in the databases of the National Center for Biotechnology Information and DNA Database of Japan using the BLAST (Altschul et al., 1997) and FASTA programs (Lipman \& Pearson, 1985). The 16S rRNA gene sequences of strains FUT3661 ${ }^{\mathrm{T}}$ and Asr22- $7^{\mathrm{T}}$ were most closely related to the sequence of a marine, facultative iron(III)-reducing bacterium, F. balearica $\mathrm{PAT}^{\mathrm{T}}$, isolated from the surface sediment of a harbour (Rosselló-Mora et al., 1995) with 93.8 and $93.7 \%$ similarity, respectively. Phylogenetic analysis was performed using MEGA3 software (Kumar et al., 2004). The Kimura two-parameter model was used to estimate pairwise distances. Phylogenetic trees were inferred by the neighbour-joining and maximum-parsimony methods. Bootstrap values were determined from 1000 replications. The phylogenetic tree constructed from the data indicated that strains FUT3661 ${ }^{\mathrm{T}}$ and Asr22-7 ${ }^{\mathrm{T}}$ clustered within the Gammaproteobacteria encompassing the genus Ferrimonas, including $F$. balearica $\mathrm{PAT}^{\mathrm{T}}$ (Rosselló-Mora et al., 1995) and F. marina A4D-4 ${ }^{\mathrm{T}}$ (Katsuta et al., 2005), but represented a novel lineage (Fig. 2). DNA-DNA hybridization experiments were performed using the fluorometric microdilution plate method (Ezaki et al., 1988) to determine the genetic relatedness between strains FUT3661 ${ }^{\mathrm{T}}$ and Asr $22-7^{\mathrm{T}}$, and between the two novel strains and F. balearica $\mathrm{PAT}^{\mathrm{T}}$ and F. marina A4D$4^{\mathrm{T}}$. Strains FUT3661 ${ }^{\mathrm{T}}$ and Asr $22-7^{\mathrm{T}}$ showed a mean DNADNA relatedness of $2.9 \%$ when their DNAs were used individually as labelled DNA probes for cross-hybridization. These data demonstrate that strains FUT3661 ${ }^{\mathrm{T}}$ and

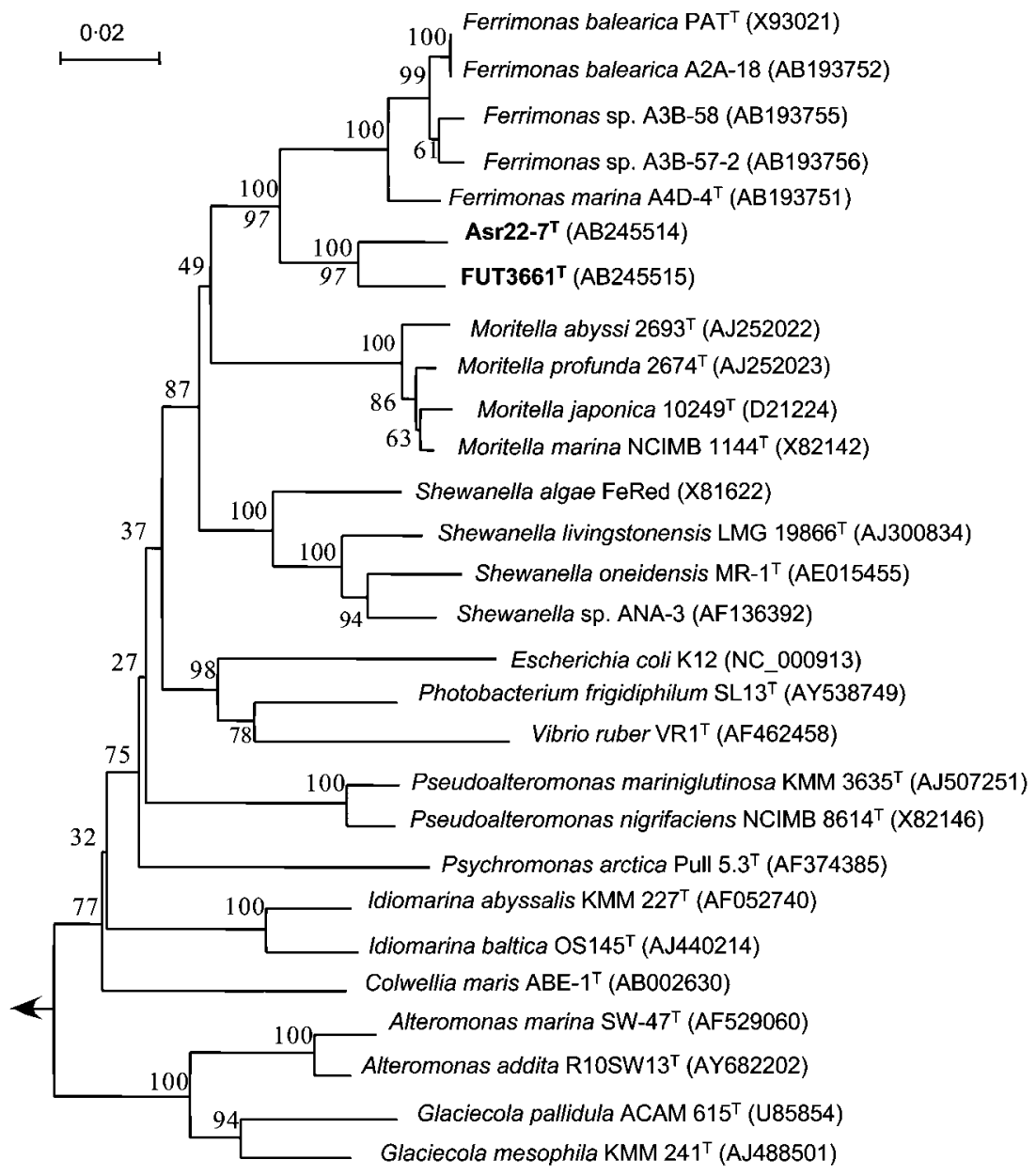

Fig. 2. Phylogenetic tree of representative strains within the order Alteromonadales and strains FUT3661 ${ }^{\top}$ and Asr22- $7^{\top}$ inferred from 16S rRNA gene sequences based on the neighbour-joining method. Numbers beside branch points indicate bootstrap percentages determined from 1000 replications; numbers in italics indicate bootstrap percentages determined by the maximum-parsimony method. Bacillus subtilis was used as the outgroup (not shown). Bar, 2 substitutions per 100 nt. 
Asr22-7 ${ }^{\mathrm{T}}$ represent members of different genomic species. Strain FUT3661 ${ }^{\mathrm{T}}$ showed mean DNA-DNA relatedness of $0.4 \%$ to F. balearica $\mathrm{PAT}^{\mathrm{T}}$ and $0 \cdot 2 \%$ to F. marina A4D- ${ }^{\mathrm{T}}$. Strain Asr $22-7^{\mathrm{T}}$ showed mean DNA-DNA relatedness of $5 \cdot 9 \%$ to F. balearica $\mathrm{PAT}^{\mathrm{T}}$ and $9 \cdot 2 \%$ to F. marina $\mathrm{A} 4 \mathrm{D}-4^{\mathrm{T}}$.

Strains FUT3661 ${ }^{\mathrm{T}}$ and Asr22-7 ${ }^{\mathrm{T}}$ can be separated from their nearest relatives, i.e. members of the genus Ferrimonas, based on their genotypic and phenotypic characteristics (Table 1 and Fig. 1). Moreover, strains FUT3661 ${ }^{\mathrm{T}}$ and Asr22- $7^{\mathrm{T}}$ can each be considered to represent a different species based on DNA-DNA hybridization analysis together with differences in DNA $\mathrm{G}+\mathrm{C}$ content and in their phenotypic properties (Table 1 and Fig. 2; see also Supplementary Figs S2, S3 and S4 in IJSEM Online). We propose the names Ferrimonas futtsuensis sp. nov. and Ferrimonas kyonanensis sp. nov. to accommodate these two novel strains.

\section{Description of Ferrimonas futtsuensis sp. nov.}

Ferrimonas futtsuensis (fut.tsu.en'sis. N.L. fem. adj. futtsuensis from Futtsu, the place of isolation).

Cells are Gram-negative rods $(0 \cdot 7-0 \cdot 9 \times 0 \cdot 4-0 \cdot 7 \mu \mathrm{m})$ and motile by a polar flagellum. No spores are observed. Mesophilic, facultatively anaerobic, chemo-organotroph. Circular, opaque, beige colonies are formed after 2 days on MA plates at $30^{\circ} \mathrm{C}$. Growth occurs at $15 \cdot 0-30 \cdot 0{ }^{\circ} \mathrm{C}$, with an optimum at $30 \cdot 0{ }^{\circ} \mathrm{C}$. The $\mathrm{pH}$ range for growth is $6 \cdot 0-9 \cdot 0$. $\mathrm{NaCl}$ is required for growth; growth occurs at $0 \cdot 7-5 \cdot 0 \%$ $(\mathrm{w} / \mathrm{v})$, with an optimum at $3 \cdot 0 \%$. Major isoprenoid quinones are MK-7, Q-7 and Q-8. Major cellular fatty acids are $\mathrm{C}_{16: 0}(19 \cdot 4 \%), \mathrm{C}_{16: 1} \omega 9 c(20 \cdot 4 \%)$ and $\mathrm{C}_{18: 1} \omega 9 c(15 \cdot 9 \%)$. Growth is observed with yeast extract, tryptone, Casamino acids, pyruvate, fumarate, propionate and lactate as the electron donor and carbon source in the presence of selenate. Gelatin is hydrolysed. Utilizes selenate, iron(III) oxyhydroxide, iron(III) citrate, arsenate, manganese(IV) oxide, elemental sulfur, thiosulfate and oxygen as an electron acceptor. Can reduce selenate to elemental selenium. The $\mathrm{G}+\mathrm{C}$ content of the genomic DNA is $58 \cdot 1 \mathrm{~mol} \%$ (as determined by HPLC).

The type strain, FUT3661 ${ }^{\mathrm{T}}\left(=\right.$ NBRC $101558^{\mathrm{T}}=\mathrm{DSM}$ $18154^{\mathrm{T}}$ ), was isolated from Futtsu beach on the coast of Tokyo Bay, Japan.

\section{Description of Ferrimonas kyonanensis sp. nov.}

Ferrimonas kyonanensis (ky.o.nan.en'sis. N.L. fem. adj. kyonanensis from Kyonan, the place of isolation).

Cells are Gram-negative rods $(0 \cdot 7-1 \cdot 1 \times 0 \cdot 5-0 \cdot 8 \mu \mathrm{m})$ and motile by a polar flagellum. No spores are observed. Mesophilic, facultatively anaerobic, chemo-organotroph. Circular, opaque, beige colonies are formed after 2 days on $\mathrm{MA}$ at $25^{\circ} \mathrm{C}$. Growth occurs at $15 \cdot 0-32 \cdot 5^{\circ} \mathrm{C}$, with an optimum at $25 \cdot 0-28 \cdot 0^{\circ} \mathrm{C}$. The $\mathrm{pH}$ range for growth is $6 \cdot 0-9 \cdot 0 . \mathrm{NaCl}$ is required for growth; growth occurs at
$2 \cdot 0-5 \cdot 0 \%(\mathrm{w} / \mathrm{v})$, with an optimum at $2 \cdot 0 \%$. Major isoprenoid quinones are MK-7, Q-7 and Q-8. Major cellular fatty acids are $\mathrm{C}_{16: 0}(15 \cdot 6 \%), \mathrm{C}_{16: 1} \omega 9 c(28 \cdot 5 \%)$ and $\mathrm{C}_{18: 1} \omega 9 c(10.9 \%)$. Growth is observed with yeast extract, tryptone, Casamino acids, pyruvate and lactate as the electron donor and carbon source in the presence of selenate. Gelatin and arginine are hydrolysed. Utilizes selenate, iron(III) oxyhydroxide, iron(III) citrate, arsenate, manganese(IV) oxide, elemental sulfur, nitrate and oxygen as an electron acceptor. Reduces selenate to elemental selenium. The $\mathrm{G}+\mathrm{C}$ content of the genomic DNA is $57 \cdot 2 \mathrm{~mol} \%$ (as determined by HPLC).

The type strain, Asr22- $7^{\mathrm{T}} \quad\left(=\mathrm{NBRC} \quad 101286^{\mathrm{T}}=\mathrm{DSM}\right.$ $\left.18153^{\mathrm{T}}\right)$, was isolated from the alimentary tract of littleneck clams collected from Kyonan beach on the coast of Tokyo Bay, Japan.

\section{Acknowledgements}

We are indebted to Kenji Tanaka for assistance with transmission electron microscopy, Yayoi Sakiyama for assistance with the LC-MS and HPLC, Shams Tabrez Khan for assistance with the API 20 NE system and Takahiro Iwami and Kozue Anzai for their skilled technical assistance. We are also indebted to Koji Mori for his support in the field. This study was supported by $\mathrm{New}$ Energy and Industrial Technical Development Organization (NEDO).

\section{References}

Altschul, S. F., Madden, T. L., Schäfer, A. A., Zhang, J., Zhang, Z., Miller, W. \& Lipman, D. J. (1997). Gapped BLAST and PSI-BLAST: a new generation of protein database search programs. Nucleic Acids Res 25, 3389-3402.

Cline, J. D. (1969). Spectrophotometric determination of hydrogen sulfide in natural waters. Limnol Oceanogr 14, 454-458.

Collins, M. D., Pirouz, T., Goodfellow, M. \& Minnikin, D. E. (1977). Distribution of menaquinones in actinomycetes and corynebacteria. J Gen Microbiol 100, 221-230.

Conde, J. E. \& Sanz Alaejos, M. (1997). Selenium concentrations in natural and environmental waters. Chem Rev 97, 1979-2003.

Delong, E. F. (1992). Archaea in coastal marine environments. Proc Natl Acad Sci U S A 89, 5685-5689.

Ezaki, T., Hashimoto, Y., Takeuchi, T., Yamamoto, H., Liu, S.-L., Matsui, K. \& Yabuuchi, E. (1988). Simple genetic method to identify viridans group streptococci by colorimetric dot hybridization and fluorometric hybridization in microdilution wells. J Clin Microbiol 26, 1708-1713.

Fujita, M., Ike, M., Nishimoto, S., Takahashi, K. \& Kashiwa, M. (1997). Isolation and characterization of a novel selenate-reducing bacterium, Bacillus sp. SF-1. J Ferment Bioeng 83, 517-522.

Hucker, G. J. \& Conn, H. J. (1923). Method of Gram Staining. New York State Agriculture Experiment Station Technical Bulletin no. 93. Ithaca, NY: New York State Agriculture Experiment Station.

Katsuta, A., Adachi, K., Matsuda, S., Shizuri, Y. \& Kasai, H. (2005). Ferrimonas marina sp. nov. Int J Syst Evol Microbiol 55, 1851-1855.

Klonowska, A., Heulin, T. \& Vermeglio, A. (2005). Selenite and tellurite reduction by Shewanella oneidensis. Appl Environ Microbiol 71, 5607-5609. 
Kumar, S., Tamura, K. \& Nei, M. (2004). MEGA3: integrated software for molecular evolutionary genetics analysis and sequence alignment. Brief Bioinform 5, 150-163.

Lipman, D. J. \& Pearson, W. R. (1985). Rapid and sensitive protein similarity searches. Science 227, 1435-1441.

Lovley, D. R. \& Phillips, E. J. (1986). Organic matter mineralization with reduction of ferric iron in anaerobic sediments. Appl Environ Microbiol 51, 683-689.

Mesbah, M., Premachandran, U. \& Whitman, W. (1989). Precise measurement of the $\mathrm{G}+\mathrm{C}$ content of deoxyribonucleic acid by high performance liquid chromatography. Int J Syst Bacteriol 39, 159-167.

Porter, K. G. \& Feig, Y. S. (1980). The use of DAPI for identifying and counting microflora. Limnol Oceanogr 25, 943-948.

Rosselló-Mora, R. A., Ludwig, W., Kämpfer, P., Amann, R. \& Schleifer, K.-H. (1995). Ferrimonas balearica gen. nov., spec. nov., a marine facultative $\mathrm{Fe}(\mathrm{III})$-reducing bacterium. Syst Appl Microbiol 18, 196-202.

Stolz, J. F. \& Oremland, R. S. (1999). Bacterial respiration of arsenic and selenium. FEMS Microbiol Rev 23, 615-627.

Stolz, J. F., Ellis, D. J., Switzer Blum, J., Ahmann, D., Lovley, D. R. \& Oremland, R. S. (1999). Sulfurospirillum barnesii sp. nov. and Sulfurospirillum arsenophilum sp. nov., new members of the Sulfurospirillum clade of the epsilon Proteobacteria. Int J Syst Bacteriol 49, 1177-1180.

Switzer Blum, J., Burns Bindi, A., Buzzelli, J., Stolz, J. F. \& Oremland, R. S. (1998). Bacillus arsenicoselenatis, sp. nov., and Bacillus selenitireducens, sp. nov.: two haloalkaliphiles from Mono
Lake, California that respire oxyanions of selenium and arsenic. Arch Microbiol 171, 19-30.

Switzer Blum, J., Stolz, J. F., Oren, A. \& Oremland, R. S. (2001). Selenihalanaerobacter shriftii gen. nov., sp. nov., a halophilic anaerobe from deep sea sediments that respires selenate. Arch Microbiol 175, 208-219.

Tamaoka, J. \& Komagata, K. (1984). Determination of DNA base composition by reversed-phase high-performance liquid chromatography. FEMS Microbiol Lett 25, 125-128.

Tamura, H., Goto, K., Yotsuyanagi, T. \& Nagayama, M. (1974). Spectrophotometric determination of iron (II) with 1,10-phenanthroline in the presence of large amounts of iron (III). Talanta 21, 314-318.

von Wintzingerode, F., Göbel, U. B., Siddiqui, R. A., Rösick, U., Schumann, P., Frühling, A., Rohde, M., Pukall, R. \& Stackebrandt, E. (2001). Salana multivorans gen. nov., sp. nov., a novel actinobacterium isolated from an anaerobic bioreactor and capable of selenate reduction. Int J Syst Evol Microbiol 51, 1653-1661.

Widdel, F. \& Bak, F. (1992). Gram-negative mesophilic sulfatereducing bacteria. In The Prokaryotes, 2nd edn, vol. 4, pp. 3352-3378. Edited by A. Balows, H. G. Trüper, M. Dworkin, W. Harder \& K. H. Schleifer. New York: Springer.

Widdel, F., Kohring, G.-W. \& Mayer, F. (1983). Studies on dissimilatory sulfate-reducing bacteria that decompose fatty acids. III. Characterization of the filamentous gliding Desulfonema limicola gen. nov., sp. nov., and Desulfonema magnum sp. nov. Arch Microbiol 134, 286-294.

Zhang, Y., Siddique, T., Wang, J. \& Frankenberger, W. T., Jr (2004). Selenate reduction in river water by Citrobacter freundii isolated from a selenium-contaminated sediment. J Agric Food Chem 52, 1594-1600. 